\title{
Being Sophia Burset: Communicating Trans Identity in Orange is the New Black
}

\author{
Angela Zottola ${ }^{1 *}$ \\ (iD) 0000-0003-2356-5023 \\ ${ }^{1}$ University of Turin, ITALY \\ *Corresponding author: angela.zottola@unito.it
}

Citation: Zottola, A. (2022). Being Sophia Burset: Communicating Trans Identity in Orange is the New Black. Online Journal of Communication and Media Technologies, 12(1), e202206. https://doi.org/10.30935/ojcmt/11463

ARTICLE INFO

Received: 27 Sep 2021

Accepted: 27 Nov 2021

\section{ABSTRACT}

This article discusses the creation of a discursive space for trans identity in the TV series Orange is the New Black. It explores the ways in which the character of Sophia Burset is defined discursively and through the linguistic choices made by the scriptwriter in designing the script. The analysis compares the original English dialogue and its dubbed Italian adaptation. It highlights two major patterns which reveal how cisgender characters in the series talk about trans identity and how self-representation is achieved. The study offers a close discourse analysis of selected scenes from the seven Seasons the series is comprised of, drawing from the framework of Sociocultural Linguistics and from studies in the field of Audiovisual Translation, offering itself as a further brick in the construction of a trans linguistics.

Keywords: transgender identity, English vs. Italian, TV series, discourse analysis, OITNB

\section{INTRODUCTION}

The constant exposure to mediatic products to which people are subjected plays a major role in forming people's views (Bednarek, 2018, p. 5; Turkle, 1995) "lead[ing] to the construction and reproduction of social discourses" (Balirano, 2014, p. 45). In many cases these products are created and distributed in English speaking countries, such as the USA or the UK and then make their way around the world either in its original format or in translated versions (Bednarek, 2018, p. 3). An example of this trend is Italy, traditionally a country in which translation of audiovisual products has been an imperative (Audissino, 2012; Chaume, 2007). In 2006, discussing the advantages and disadvantages of audiovisual translation (AVT) and its socio-cultural relevance, Yves Gambier (2006, p. 5) suggested "the AV media certainly play a major linguistic role today"; and indeed, they have facilitated the discussion around LGBTIQ+ issues, as the growing number of films and TV series based on its representation demonstrate (Zottola, 2018; 2021). However, despite the more positive scenario for LGBTIQ+ people, the portrayal of these identities in the media remains problematic (Fejes \& Petrich, 2006; Sandrelli, 2016; Zottola, 2021). Social media and the press, as well as any form of televised or cinematic production, are places in which the problem of assuring an inclusive and non-discriminatory depiction of the LGBTIQ+ community remains at stake (see Nölke, 2017). As Díaz Cintas and Anderman (2009, p. 1) argue, "the media is omnipresent: to inform, arguably sometimes to misinform, to sell, to entertain, to educate". However, this platform is not simply powerful in its status of institutional social actor, the power "lies to a considerable extent in [its] practices as gatekeepers" (Johnson \& Milani, 2010, p. 5). As Johnson and Milani (2009, p. 5) maintain, "the media, constrained or pressed by particular economic and political imperatives [has the power to] open up discursive spaces [...], thereby giving a public voice to a variety of social actors who compete with each other in staking various claims regarding what counts as legitimate knowledge in the domain of language (Blommaert, 1999; Johnson, 2001)", but also to shut down or manipulate these spaces and discourses accordingly, deeming them as not legitimate. In addition, being the media environment a multi-layered one, it can generate meaning and representations on different levels. Audiovisual texts, in the different modes that compose them, can play a crucial role in the representation of minorities and communities which undergo

Copyright (c) 2022 by authors; licensee OJCMT. This article is an open access article distributed under the terms and conditions of the Creative Commons Attribution License (http://creativecommons.org/licenses/by/4.0/). 
discrimination by providing a space in which discourses can be engendered and popularized. This is in line with Zimman and Hall's (2010, p. 166) assertion that bodies "are imbued with meaning through discourse". In this sense, films and TV series have always been prime actors in the construction of linguistic, social and cultural identities (Bleichenbacher, 2008).

In this article, I explore how a discursive space is created for trans identities in the media by investigating the television series Orange is the New Black (OITNB). One of the characters on the series is Sophia Burset, a transgender woman convicted for credit-card fraud, played by Laverne Cox, the first openly trans Black actress. I consider the linguistic and discursive choices made to represent this character's identity via the analysis of selected segments of dialogues directly involving Sophia. The paper, not only seeks to explore the way in which this character is presented on the series, but also to compare the original English dialogue and its Italian dubbed version. The analysis concentrates on allocutivity markers, in particular on some of the aspects involved in linguistically encoding the addressee in conversation, - i.e., the lexical choices made to address Sophia, such as pronouns, adjectives or nouns that directly refer to her as a transgender person, focusing on the way transgender identity is constructed through language and in translation.

By means of a qualitative approach, I draw from the seminal work by Bucholtz and Hall (2005) on identity representation and from the literature on dubbing (Chaume, 2012; Minutella, 2007; Pavesi, 2005) and on audiovisual practices in the translation of taboo and gender specific language (Ranzato, 2015; Sandrelli, 2016). This study offers itself as a further brick in the construction of a trans linguistics (Di Martino, 2019; Zimman, 2020) as "both an exploratory and an activist process" (Di Martino, 2019, p. 17).

\section{OITNB: BACKGROUND, DATA COLLECTION, AND METHOD}

Loosely based on the memoir written by Piper Kerman (Kerman, 2010), OITNB was created by Jenji Kohan for Netflix (Grant, 2004, pp. 249-251). Season One was released in the USA on July 11, 2013, and a new season was released every following year until 2019. In Italy, season One was released on June 6, 2014, and the second season was released in the same year. The rest of the seasons followed the one-year pattern described above. The series is comprised of ninety-one episodes, thirteen per each of the seven seasons produced ${ }^{1}$.

OITNB centres on the life of a group of inmates in the Litchfield Penitentiary, a minimum-security female Federal prison in Upstate New York. The main character is Piper Chapman (Taylor Schilling), convicted to 15 months in jail for transporting a suitcase full of drug money for her former, international drug dealer girlfriend, Alex Vause (Laura Prepon). The women are in the same prison and, while Piper narrates her experience, the other inmates are introduced to the audience. Among them is Sophia Burset, convicted for stealing money from credit cards to finance her gender affirmation surgery. Before transition, Sophia was a firefighter. She is married to Crystal and has a son, Michael. While her wife is supportive of her choices, her son Michael turns her in to the police to avenge himself for the embarrassment he feels she has caused. In prison, Sophia works as a hair stylist. In season One, she has a more prominent role compared to the other seasons where she is given less and less space. Through several plot twists, her presence in the series is drastically reduced from season Four. In season Six she accepts a deal and is released from prison. In season Seven she appears only once and is represented in her own hair salon as a happy and accomplished hair stylist. Her character is based on Vanessa Robinson, from Kerman's memoir.

For the analysis, all episodes were viewed and those including a scene in which Sophia is present or talked about were selected. The scenes were manually transcribed in both the English and the Italian version, and then analysed. Table 1 shows the episodes considered for each season.

The investigation carried out is twofold. First, I focus on the original English dialogue and explore how transgender identity is constructed in OITNB through the linguistic and lexical choices made by the scriptwriter. Then, I investigate the way in which the identity is translated and adapted into Italian via the analysis of the translation choices made in the dubbed version. Identity construction and representation is addressed through the lenses of Bucholtz and Hall's (2005) Identity Construction Principles.

\footnotetext{
Information on OITNB was retrieved from the official websites: http://oitnb.com/ and http://www.imdb.com/title/tt2372162/ (Last accessed August 3, 2019).
} 
Table 1. Episodes included in the analysis per season

\begin{tabular}{ll}
\hline Season & Episodes included \\
\hline One & $1,2,3,5,6,7,9,10,13$ \\
Two & $2,3,4,6,7,8,10,11$ \\
Three & $1,4,6,7,8,9,10,11,12,13$ \\
Four & $2,4,6,8,11,12$ \\
Five & $1,2,4$ \\
Six & $6,11,13$ \\
Seven & 11 \\
\hline
\end{tabular}

\section{Representing and Translating Trans Identity}

\section{Representation}

In the last decade, trans identities have been increasingly under scrutiny in the field of linguistics (Zimman, 2020). In the media, many studies have underlined the necessity of an effort towards a more inclusive representational characterization. In the press, misgendering, sexualisation, and medicalization have been identified as some of the most frequent patters used to represent trans people (Baker, 2014; Billard, 2016; Capuzza, 2015; Gupta, 2019; Zottola, 2021). On TV and in the cinema, the presence of transgender characters or the narration of trans stories has increased sensibly (Capuzza \& Spencer, 2016; Leung, 2016; Poole, 2017; Zottola, 2021). Trans representation has been investigated on the small screen, in talk shows for example (Gamson, 2001), documentaries (Hladky, 2013) and TV series (Capuzza \& Spencer, 2016; Monello, 2020), as well as on the big screen, in famous production such as Dallas Buyers Club (Dore \& Zarrelli, 2018).

To look at the multiple aspects that compose identity without leaving any of them out I draw from Sociocultural Linguistics. Specifically, in this study I consider three of the five principles proposed by Bucholtz and Hall (2005) which summarize different existing theories on identity construction through language. One way to comprehend identity is by considering it as housed in the individual's mind, as the authors explain with the emergence principle. In this view, Bucholtz and Hall $(2005$, p. 587) maintain that identity is defined by using language to reflect the individual's internal mental state. Identity can also be defined by major social categories such as age, gender, or social status as in the case of the positionality principle. In this perspective, it is shaped according to the "temporary roles and orientations assumed by participants" (Bucholtz \& Hall, 2005, p. 591), which are rendered through language. Given the nature of identity, interconnected in its number of layers and features, the principles identified by the two scholars can, in some instances, also overlap. This is the case of the third principle identified in the analysis of the dialogues of OITNB, the indexicality principle, which focuses on the creation of semiotic links between linguistic forms and social meaning. This principle insists on specific linguistic strategies (such as labels or implicatures) through which identity is constructed (Bucholtz \& Hall, 2005, pp. 593-594). Section Who is Sophia? Analysing the Dialogues includes some examples of how language use in the series fits these principles.

\section{Translation}

The issue of Transgender Studies Quarterly (November 2016) dedicated to the investigation of the translation of 'transgender' as a noun, as an experience or as a "domain of translational practices" (Gramling \& Dutta, 2016, p. 35), discusses the need to find a way to frame, represent, describe and, most of all, translate transgender identity. The field of Translation Studies has promptly recognized this need and started to fill the gap (Baldo et al., 2021; Robinson, 2019; Rose, 2020). In the specific field of cinematic productions, Leung points out that "what is clear is that there is no one way - not in a title, in a choice of pronoun, even less in a translation practice - to capture the experience, feelings and identity of the people the film is portraying" (Leung, 2016, p. 434).

The case study presented here focuses on the original dialogues of OITNB and its Italian dubbed version. Dubbing is viewed as the creation of a new script in the target language, used to replace the original dialogue and make it accessible to the target audience (Chaume, 2012; Pavesi, 2005). The dubbed script is the result of a very complex process, that involves not only translation but manipulation and adaptation of the text as well (Minutella, 2007, p. 35), particularly due to the many technical constraints related to dubbing. The translator must bear in mind a whole range of verbal and visual elements: Lip synchronization, facial expression, and 
body movement. It is necessary that the utterances always match the context in which they are being uttered, their length in the source language, the gestures associated with that specific assertion, the pauses in speaking. Thus, despite the process of translation being described as a creative one, creativity often finds a restraint in these features (Pavesi, 2018).

The application of the translation practices produces a new script rooted in specific linguistic choices. The choices made by the translator and adapter not only influence the comprehensibility of the script but entail specific political and socio-cultural assumptions. The lexicon employed implies a specific perspective, particularly when dealing with issues like that of addressing the LGBTIQ+ community (Ranzato, 2015).

In Italy, the translation of dialogues is assigned to the dialoghista, who translates the dialogues and adapts them for dubbing. The job of the dialoghista goes beyond translation, since, as anticipated above, the numerous constraints of dubbing require adaptation (Fois, 2012; Paolinelli \& Di Fortunato, 2005). While we need to keep these constraints in mind when we read the translated version, Fois (2012) reminds us that this practice is necessary when the target text is at risks of not being received or understood by the audience.

Specifically, Netflix's guidelines for dubbing suggest that dialogues should not be censored or softened and that the tone and register should match original dialogue ${ }^{2}$.

Lastly, a great deal has been said about the way in which taboo language and sensitive references are translated into Italian in the context of audiovisual products. Most of the studies highlight a general tendency to tone down or censor these types of references, especially in dubbing (Bruti, 2009; Ranzato, 2012; Sandrelli, 2016; Zanotti, 2012).

\section{Who is Sophia? Analysing the Dialogues}

Due to space constraints, in this paper I limit the discussion to the two most prominent patterns which, among others, contribute to the representation of Sophia - and trans identity, in OITNB. The first one considers the linguistic and discursive choices made by other cisgender characters to describe Sophia and describe trans identity in their perspective. The second pattern provides insights into self-representation, as I explore instances in which Sophia talks about herself and describes her identity in her own terms.

\section{About Sophia}

This section focuses on the terminological issues and lexical choices adopted by other characters to refer to Sophia, both in English and Italian.

The representation of Sophia that we grasp through the words of these characters seems to paint a rather confusing picture, in which people are unable to make informed decision about the type of linguistic choices most appropriate to refer to her. Indeed, one of the features identified in these examples is misgendering through pronouns or titles. The most common pattern suggests that when the character is unsure of which pronoun or title to use, they resort to using both the feminine and masculine references contemporarily, as in (1), (2) and (3)

(1) ANITA: I wouldn't let that he-she touch my hair with a $\mathbf{1 0 - f o o t ~ p o l e . ~}$

ANITA: Non mi farei toccare i capelli da quel lui/lei neanche con una pertica (Season 1, Episode 3).

(1) shows how one of the fellow inmates chooses to refer to Sophia by using the double pronoun 'he-she'. The use of 'he-she' conveys a derogatory indefiniteness. By using the combination 'he-she', the speaker wants to highlight the in-between nature of the character of Sophia, who cannot be placed in the binary system entailed by given pronouns, thus, re-enforcing the tradition according to which language users discursively employ the pronoun 'he' to refer to men and the pronoun 'she' to refer to women, and suggesting that Sophia sits in-between this dichotomy. This becomes even more negative and derogative when the speaker premodifies the pronoun with the determiner 'that', indicating uncertainty about the gender of the subject of the conversation while also distancing herself through recourse to this distal deictic expression. The pattern is

\footnotetext{
${ }^{2}$ https://partnerhelp.netflixstudios.com/hc/en-us/articles/214807888-Dubbed-Audio-Style-Guide-Lip-Sync-Dubbing

${ }^{3}$ Bold is added to highlight elements in the analysis.
} 
rendered in the same way into Italian where not only we find the use of double pronoun lui/lei (he/she), but also the deictic distancing using quel (that).

(2) HEALY: I got a tranny camped out in my hallway yelling about her hormones!

FIGUEROA: He can suck it up. She. Jesus.

HEALY: Ho una trans accampata di fronte il mio ufficio che strilla per avere i suoi ormoni.

FIGUEROA: Quello può rassegnarsi. Quella... Gesù (Season 1, Episode 3).

In (2), the head of the prison, Miss Figueroa, is confused about which pronoun to use to address Sophia, and thus resorts to using them both. In this case, differently from example (1), the woman first uses the masculine pronoun and later tries to correct herself using the feminine, however the imprecation that follows signals how she is annoyed by this. In Italian, the personal pronoun is replaced by the demonstrative pronoun which still retains the gendered suffix, but also expresses some distancing, as in the previous example. We should also note the use of the derogatory term 'tranny' in this exchange, which since the beginning sets the tone for a negative connotation later reinforced by the misgendering. The term is translated in Italian with the word trans premodified by the feminine indefinite article, thus using the adjective as a noun. Although the Italian version does not report an explicit derogatory term, its use in an unwelcomed grammatical function preserves the negative connotation of the exchange. This can be defined as a process of sanitation (Ranzato, 2015) of the text, where a more derogatory instance is downgraded. This same process whereby tranny is translated as trans, is also found in another instance (Season 1, Episode 5) where Big Boo is talking to Sophia about a piece of news she had read.

Similarly, when titles are used, the double occurrence can be observed (see (3) below).

(3) SALESCLERK: Sir. Ma'am. You need to pay for those.

COMMESSO: Signore. Signora. Quelle le deve pagare (Season 1, Episode 3).

We should note that, although Sophia is a woman, the first pronoun used in the dialogues, in all three examples, is always the masculine one. The representation of trans identity through the perspective of cischaracters seems to adhere to the positionality principle (Bucholtz \& Hall, 2005). While the characters seem to be able to rely solely on existing gender categories to define Sophia, they struggle to position her within the binary labels available. The reason behind these choices, given that Sophia is represented as a trans woman who externally presents adhering to the traits that our society associates to women and has undergone gender affirmation surgery, can be, in my opinion, associated to an explicit desire of the scriptwriter to provide the audience with a complicated representation of this trans character. By positioning Sophia in a specific category, the other characters are also defining themselves as not being that gender, or not having those physical characteristics, or not belonging to that gender group, which strengthens the mounting concept of "otherness" (Coupland, 2010) through which Sophia is represented. Along the same lines, are the following two examples in which Sophia is referred to as a 'lady-man'.

(4) PENNSATUCKY: What do you know about a load-bearing pipe, lady man?

PENNSATUCKY: E tu che ne sai di tubi bella maschiona? (Season 1, Episode 5).

(5) MORELLO: Oh! How does that work, with you being a lady-man and all? Do you and his mother both celebrate the day?

MORELLO: Oh! Come funziona con voi che siete donne uomini? Tu e sua madre festeggiate insieme la giornata? (Season 3, Episode 1).

The examples are taken from two different seasons (one and three) and the context of use and translation differ. While in (4) the fellow inmate is explicitly trying to insult Sophia, in (5) Morello is not willingly being discriminatory, on the contrary she is asking Sophia to explain to her how Mother's Day works for couples in 
which one of the two identifies as trans. From a representational perspective, this still provides an uncertain illustration of the situation for the audience. The translation into Italian is different in the two examples, while in (5) we see a direct translation of the original donne uomini (women men), in (4) the expression is rendered with bella maschiona (beautiful macho, both terms including the feminine suffix $-a$ ). In this translation the adapter choses to signal the dual gender use by choosing a specifically masculine noun and adding the feminine suffix, this construction retains the derogatory intention of the original.

The difficulty in defining Sophia, in collocating her in a specific category or attributing a label to her identity can also be observed in other attempts at describing her within the dialogues in which pronouns or titles are not necessarily involved, rather the focus is on her person more generally speaking. A longer example is reported below that exemplifies this type of pattern.

(6) PORNSTACHE: Now, that right there? That's a whole different species, my friend.

$[\ldots]$

BENNETT: Shit is wild, right? Freaky. Freaky-deaky. Freaktown.

PORNSTACHE: Cyborg pussy. I bet it's fucking perfect.

BENNETT: Don't tell me you'd hit that?

PORNSTACHE: I live in the present, not in the past. Besides, she used to have a dick, and so she knows what it likes.

PORNOBAFFO: Invece quella la? È tutta un'altra razza.

$[\ldots]$

BENNETT: Matta vera, eh? Pazza, pazza al cubo, proprio da manicomio.

PORNOBAFFO: Una fica cyborg. Scommetto che è perfetta.

BENNETT: Non dirmi che te la faresti!

PORNOBAFFO: Vivo nel presente, non nel passato. E poi una volta aveva il cazzo...sa cosa gli piace (Season 1, Episode 3).

In this dialogue between two of the guards, Sophia is described using terms that de-humanise her, but while she is sexualized by the first speaker, the second almost expresses disgust at the idea of a sexual encounter with her. In fact, Pornstache defines her as 'a whole different species' and later as a 'cyborg pussy', evaluating this positively because it could be a synonym of perfection as her genitals were 'made' and not natural. Additionally, Pornstache refers to her identity before transition implying that because she was able to experience being a man, she is more understanding of sexual pleasure for those who identify as such. Bennet chooses his words from a completely different semantic set and defines Sophia as 'wild' and 'freakydickey'.

Looking at the translation, while the original dialogue uses the word 'species', commonly associated with animals, plants and microorganisms in English, in Italian we find razza (race), which is more often related to humans ${ }^{4}$. In addition to this, 'freaky' which in the original dialogue seems to refer to her gender with the meaning of something bizarre or even grotesque, the Italian version reports the word pazza (crazy), a reference more to her personality and her mental state given the presence of the word manicomino (mental institution / asylum) used to translate 'freaktown'. The Italian version, in this case, seems to downplay the de-

4 The use of 'species' and 'race' in English was confirmed through the consultation of the COCA corpus (http://corpus.byu.edu/coca/). The collocation analysis of the two terms shows that the former is mostly related to animals, plants and microorganisms while the latter to human beings. 
humanizing aspect that we find in the English version, while nonetheless providing a negative representation of trans identity related to mental health issues.

Following the idea that Sophia is something that does not fit the definition of human, the following example displays yet another of the definitions provided in the dialogues.

(7) PENNSATUCKY: That's why this whole thing happened. God's angry that there's an abomination in the church, and if we don't get rid of "it," it's just gonna keep on happening.

PENNSATUCKY: È per questo che è capitato. Dio è arrabbiato perché c'è un abominio nella chiesa, se non ce ne liberiamo succederà di nuovo (Season 1, Episode 5).

In this episode, the church inside the prison collapses and Pennsatucky explains that it is Sophia's fault. Because she is not human, but an abomination, God has punished them all for allowing her in the church. The non-human depiction is reinforced by the use of the pronoun it, generally used in reference to objects. In Italian, the noun is translated literally, but it is not reinforced by the pronoun as the sentence is rendered impersonal, thus the use of a specific pronoun is avoided.

The last example in this section is taken from Season 3. In this part of the story, Sophia gets particularly close with Gloria given that both their children are around the same age and live nearby, but they end up having a fight in which Gloria argues to be a better mother because she is a 'real mother'.

(8) GLORIA: I am mothering. And I'm a ferocious, pissed-off, real mother, but you wouldn't know nothing about that, would you? Nah. 'Cause you ain't nothing real.

GLORIA: No io sono una madre. Una madre vera, feroce e incazzata, del resto che cosa puoi saperne tu. Ah. Non sei altro che una falsa dalla testa ai piedi (Season 3, Episode 10).

Gloria plays on an opposition between real and not real, she is biologically female thus a real woman while Sophia has nothing real, and here Gloria is referring both to her body and external appearance and to her identity, denying Sophia's true self. This construction puts an accent both on the external and the internal representations of trans identities. In Italian the adjective real is translated with an equivalent while the phrase that describes Sophia is translated with the phrase falsa dalla testa ai piedi (fake from head to toe). Sophia is not 'not real' but fake, an adjective that once again takes us back to the non-human pattern. This choice also carries a metaphorical meaning that refers to the internal representation. In fact, in Italian you can use this adjective to indicate that someone is dishonest.

By means of the other characters, the scriptwriter constructs Sophia in a way that adheres once again to the positionality principle. Indeed, in describing her, "it is not a matter of choosing one dimension of identity over others, but of considering multiple facets in order to achieve a more complete understanding of how [this] identity works" (Bucholtz \& Hall, 2005, p. 593). By forcing the representation into binary categories, the result inevitably leads to a less inclusive outcome. This is visible both in English and in Italian as the othering practices and dehumanization of the character are very strong.

\section{Sophia talks about herself}

In this section, I switch my focus from the representation of Sophia given by others to the representation she gives of herself, illustrating the second pattern offered in the dialogues of OITNB to represent/construct trans identity.

There are two main topics that emerge when analysing dialogues in which Sophia talks about herself. The first is related to the way she describes how she looks, with a specific reference to her genitalia; the other to the sacrifices and issues she had to overcome to become who she is but also to some medical aspects related to her gender affirmation surgery. It can be argued that this type of representation falls under the definition of the emergence principle, described in Section 3.1. Indeed, Sophia's gender and her identity are reflected in her internal mental state via a process of embodiment, intended here with the definition provided by Borba and Ostermann (2018, p. 90), as the "appropriation of signs that index gender and sexuality" which "enables transgender people to construct performances of gender (Butler, 1990) which contrast with their biological 
determinations, thus making their positions highly fluid". More specifically, the dialogues seem to point out that, in Sophia's perspective, her identity is first and foremost housed in her mind, possibly as a consequence of the discursive and linguistic patterns employed by others in reference to her and discussed above, and all her efforts lie in making that identity be visible to those who surround her.

Sophia speaks about herself by referring to what, according to our society's binary gender rules, makes her a woman. She is very explicit in showing how she can be considered a woman because she has a vagina, and she does not miss a chance to remind the viewer how expensive that vagina is. In (9), Piper walks in on her while using the toilet, and apologizes for invading her privacy.

(9) PIPER: Oh! Gee! I'm sorry.

BURSET: It's okay, honey, you can look. I spent a lot of money for it.

PIPER: Oh, cavolo scusa!

BURSET: Tranquilla, tesoro, puoi guardare. Mi è costata un capitale (Season 1, Episode 3).

Sophia is not bothered at all and is happy to display this part of her body on which she spent a lot of money. It is interesting to note how Sophia refers to her vagina with the pronoun 'it', giving it no gender, while in the Italian version, the feminine gender is chosen as the verb is conjugated with the feminine suffix '- $a$ '. However, this is almost a forced choice, since it is only possible to choose between masculine (i.e., '-o/-i') or feminine (i.e., '-a/-e') suffixes in Italian and the female sex organ is, by definition, feminine. Sophia considers her vagina so valuable that she compares it to a diamond in (10).

(10) BURSET: Listen, honey, I know all you care about is what you get to watch on the TV, but me and my diamond kitty here wanna prioritize things around this place.

BURSET: Senti, tesoro... lo so che l'unica cosa che ti interessa è la TV, ma io e la mia passera d'oro vogliamo dare la precedenza ad altre cose qui.

Although the pronominal choice and this reference, a diamond kitty, show a similarity to the association of her identity to inanimate / non-human references as those highlighted in the previous section, this example specifically refers to a part of her body and is used by Sophia with a positive connotation, to reinforce the idea of preciousness that she associates to her feminine body parts. The Italian translation is particularly interesting here as the translator operates what is defined as dislocation, a translation technique by which the content in the source language is substituted with a more relevant cultural reference to produce the same effect in the target audience (Gottlieb, 1992). 'Kitty' is translated with passera (female sparrow), a common vernacular expression to refer to the vagina; the pre-modifier 'diamond' (a post-modifier in Italian, where attributes of the noun are routinely placed to the right) is translated with d'oro (golden), keeping the reference to a very precious stone, and thus replacing perfectly the expression both in term of the animal and preciousness references.

She reminds the viewers about the expenses and sacrifices related to becoming a woman also in the conversation with the prison's doctor in (11).

(11) BURSET: You really think I would've eaten a bobble-head if I wanted to kill myself? Listen, Doc, I need my dosage. I've given five years, $\$ 80,000$ and my freedom for this. I'm finally who I'm supposed to be. Do you understand? I can't go back.

BURSET: Averi mangiato la testa di un pupazzo se avessi voluto suicidarmi? lo ho solo bisogno dei miei farmaci. Ho dato $\mathbf{5}$ anni della mia vita, $\mathbf{8 0 . 0 0 0}$ dollari e la mia libertà per questo. Sono finalmente chi devo essere, riesce a capirmi? Non ci torno indietro (Season 1, Episode 3).

In this example, in addition to reinforcing the idea of preciousness that she attaches to her vagina, she also adds how she not only had to sacrifice economically, but her freedom as well. She is basically explaining 
that she wanted to affirm her gender identity so badly, to become who she was supposed to be since the beginning, that she was willing to lose everything else. This concept is also found in other conversations between Sophia and the other characters, like in (12).

(12) BURSET: See, it's especially hard for me because it's taken me so long to get to this point. And I'm just not ready to give it up, you know?

SISTER: Yes, you said.

BURSET: And I sacrificed so much.

SISTER: Right.

BURSET: And I feel like finally, finally, I'm the woman that God intended me to be, you know?

BURSET: Vede, per me è particolarmente dura perché... ci ho messo molto ad arrivare a questo punto. E non sono pronta ad arrendermi, capisce?

SORELLA: Si, certo.

BURSET: Ed ho sacrificato così tanto.

SORELLA: È vero.

BURSET: Ed ora sento che finalmente... finalmente sono la donna... che Dio voleva che fossi. Mi spiego? (Season 1, Episode 5).

Here she is talking to Sister Ingalls and goes as far as to state that she is the woman that God intended her to be, that she has sacrificed a lot and is not willing to give it up. We should note in the Italian translation that all verbs and adjectives end with the feminine suffix -a in this excerpt.

Sophia repeats throughout the series and especially in season One, that she is a woman. By looking at these examples, another principle of identity representation emerges from the analysis, the indexicality principle. As Bucholtz and Hall (2005, p. 592) argue:

Identity relations emerge in interaction through several related indexical processes, including: (a) overt mention of identity categories and labels; (b) implicatures and presuppositions regarding one's own or others' identity position; (c) displayed evaluative and epistemic orientations to ongoing talk, as well as interactional footings and participant roles; and (d) the use of linguistic structures and systems.

In declaring her gender, Sophia is labelling herself, and positioning herself within the community she lives in. In this sense, it is possible to affirm that the emergence principle and the positionality principles overlap: Sophia is telling the audience who she is, she is trying to make the gender identity that is clear in her mind also be clear externally by putting herself in specific categories, using indexical references - i.e. stating she is a woman, talking about her vagina which is a body part stereotypically associated to women, but also positioning herself within the community of the female prison she is detained in.

As the seasons continue, we see that this effort to erase her past identity weakens, in fact, while she keeps signalling that she is currently a woman, some reference to her past can be found.

(13) RED: Ever look at yourself and realize how other people must see you?

BURSET: You caught the whole used-to-be-a-man thing, right?

RED: Ti è mai capitato nella vita di guardarti e vederti come ti vedono gli altri?

BURSET: Della serie una volta ero un uomo, vero? (Season 2, Episode 3). 
In (13) we can see an example from season Two, here during a conversation with Red, Sophia reminds her that she once was a man. Although the verbal processes employed clearly signal that this is a thing of the past, it is inevitable that this type of construction might be confusing for the audience who could be led to believe that this practice is acceptable when talking about trans people. This idea is strengthened by an example found in season Three.

(14) BURSET: It's just that I...was hoping I could be there to help shape him, you know? Teach him how to shave or change a tire. I might have changed, but I'm still his father.

BURSET: È solo che speravo di potergli stare accanto per aiutarlo a crescere, insegnagli a farsi la barba o cose così. Sono cambiato ma sono sempre suo padre (Season 3, Episode 8).

In (14), Sophia defines herself as her son's father: she acknowledges she has changed but nonetheless she remains her father. While this is the only masculine reference in the original version, given that English does not require gendered suffixes, in the Italian version not only Sophia positions herself in this male role but also uses the masculine suffix in the verb cambiato (changed). Her interlocutor, in this scene, is Gloria and when she refers to Sophia she uses feminine suffixes, contrary to Sophia herself.

Another similar example can be found in season Five.

(15) BURSET: You're gonna need some help. I was a firem...firefighter.

BURSET: Ti serve aiuto? Io facevo il pom...la vigile del fuoco! (Season 5 Episode 1).

In (15) Sophia almost defines herself as a fireman but halfway through the utterance she corrects herself with a gender-neutral version of the noun. In Italian, fireman is translated with the masculine noun pompiere, while the gender-neutral noun is rendered with the choice of using the feminine article to pre-modify the phrase vigile del fuoco (firefighter, literally officer of the fire). Differently from the previous two examples, here Sophia immediately corrects herself, however one could wonder why a person who so strongly argues to be identified as a woman, in a moment of chaos (the prison was facing a revolt of the inmates and many people were injured), when supposedly one is not thinking straight and just speaks from the heart, would choose a masculine noun as a first choice to describe herself.

The examples considered in this section show how the representation of Sophia's character evolves throughout the seasons despite less and less space is given to her. Nonetheless, the series offers a variety of different perspectives on trans identity, both in the original dialogue and in its Italian translation. This portrayal in the Italian scenario, in which gender identity issues are still widely perceived as a taboo, is extremely important in a country where "[d]epictions of LGBT characters repeatedly mirror and thus naturalize the desire for monogamous procreative futurity" (Heim, 2017, p. v), erasing difference.

\section{CONCLUSIONS}

In this paper, I aimed at investigating the linguistic and discursive choices made by the scriptwriter and later by the Italian dubbing translator in the identity representation of the transgender character of Sophia Burset in the TV series OITNB. A close reading of the data highlighted two major patterns. In fact, by looking at the use of given linguistic items, I discussed both the way the transgender character presents herself and the way she is depicted by other characters.

Some of the choices made in the dialogues imply that there was still some degree of uncertainty in the representation of transgender identity when the dialogues were created. This is retraceable on a linguistic and strictly grammatical level, see for example the use of pronouns or nouns chosen to refer to Sophia, but on a more general level in relation to the very conceptualization of going beyond the binary and heteronormative reality that the audience is used to. The lack of a specific lexicon, of an inclusive language, is also noticeable in the Italian translations.

As Butler (1988, p. 519) contends, "gender is instituted through the stylization of the body and, hence, must be understood as the mundane way in which bodily gestures, movements, and enactments of various kinds constitute the illusion of an abiding gendered self." Although fictional, representation in audiovisual products 
is also performed through the body, and the choices made by scriptwriters and casting crews in relation to this matter are not to be underestimated. Some TV series have already made a step forward towards more inclusive products. However, more work still needs to be done. As Ranzato (2015, pp. 1-2) has pointed out in relation to the use of lexicon:

Lexicon analysis can indeed be useful to unveil ideological manipulation in translation, but it can also tell us much about the language and cultural systems at play in the translation process, by decoding the sets of representations through which language is imbued with cultural meaning for a certain community.

Lexical choices were under the spotlight here. OITNB appears to reflect the uncertainty and confusion that can still be registered in society's attitude towards transgender identity. Disorientation concerns the lexicon related to this community, despite the many websites and organizations providing advice and guidelines for an accurate use of terminology ${ }^{5}$. This observation is true both for the choices concerning the representation of transgender identity in the source and in the target text.

Focusing on the Italian translation of OITNB, this was mostly accurate, even though it undoubtedly underwent a process of "sanitisation" (Ranzato, 2015, p. 19), as we can see in (2) with the translation of the term tranny or in (12) with the use of feminine suffix to signal Sophia identity. In the case study presented here, this process has specifically taken the form of a hedging of the topic, a strategy which does not result in blatant forms of censorship but in a subtler form of manipulation. Additionally, as scholars such as Bucaria (2009, p. 27) has pointed out in the past:

The lack of consistency in the translational choices even within the same series seems to indicate the absence of generalized guidelines and the existence of a certain level of arbitrariness influencing translational choices in Italy's contemporary dubbing industry.

Eight years have passed since the first season of OITNB aired in the USA, since then many things have changed for trans people in terms of gaining more visibility and having many rights recognized. At the same time, equality and end of discrimination still seems very far, in the USA, in Italy and worldwide. The show gained visibility for the topics discussed and the representation of different minorities: it is crucial for shows such as this one to offer a representation of identities and minority groups which can empower them and inform people of the reality and struggles that these communities must overcome. While OITNB in part does this some of the language choices still reiterate and reinforce specific stereotypes related to gender identity as well as discriminatory and non-inclusive practices. I hope this study will encourage reflection and change, thus becoming another brick for the construction of a trans linguistics aimed at both exploring and practically impacting trans realities.

Funding: Author received no financial support for the research and/or authorship of this article.

Declaration of interest: Author declares no competing interest.

Data availability: Data generated or analysed during this study are available from the author on request.

\section{REFERENCES}

Audissino, E. (2012). Italian "doppiaggio" dubbing in Italy: Some notes and (in)famous examples, Italian Americana, 30(1), 22-32.

Baker, P. (2014). Bad wigs and screaming mimis: Using corpus-assisted techniques to carry out critical discourse analysis of the representation of trans people in the British press. In C. Hart \& P. Cap (Eds.), Contemporary critical discourse studies (pp. 211-235). Bloomsbury.

Baldo, M., Evans, J., \& Guo T. (2021). Introduction: Translation and LGBT+/queer activism. Trans/ation and Interpreting Studies, 16(2), 185-195. https://doi.org/10.1075/tis.00051.int

\footnotetext{
${ }^{5}$ See: GLAAD at glad.org/transgender, the National Centre for Transgender Equality at http://www.transequality.org, the Stonewall Centre at the University of Massachusetts for the USA and the Movimento Identità Transsesuale at http://www.mit-italia.it/ for Italy.
} 
Balirano, G. (2014). Masculinity and representation: A multimodal critical approach to male identity constructions. Paolo Loffredo Iniziative Editoriali.

Bednarek, M. (2018). Language and television series. A linguistic approach to TV dialogue. Cambridge University Press. https://doi.org/10.1017/9781108559553

Billard, T. (2016). Writing in the margins: Mainstream news media representations of transgenderism. International Journal of Communication, 10, 4193-4218.

Bleichenbacher, L. (2008). Multilingualism in the movies: Hollywood characters and their language choices. Edinburgh University Press.

Blommaert, J. (1999). Language ideological debates. Mouton de Gruyter. https://doi.org/10.1515/9783110808049

Borba, R., \& Ostermann, A. C. (2018). Do bodies matter? Travestis' embodiment of (trans)gender identity through the manipulation of the Brazilian Portuguese grammatical gender system. In T. Milani (Ed.), Queering language, gender and sexuality (pp. 89-102). Equinox.

Bruti, S. (2009). Translating compliments and insults in the Pavia corpus of filmic speech: Two sides of the same coin? In M. Freddi \& M. Pavesi (Eds.), Analysing audiovisual dialogue. Linguistic and translational insights (pp. 143-163). CLUEB.

Bucaria, C. (2009). Translation and censorship on Italian TV: An inevitable love affair? VIAL, 6, 13-32.

Bucholtz, M., \& Hall, K. (2005). Identity and interaction: A sociocultural linguistic approach. Discourse Studies, 7(4-5), 585-614. https://doi.org/10.1177/1461445605054407

Butler, J. (1988). Performative acts and gender constitution: An essay in phenomenology and feminist theory. Theatre Journal, 40(4), 519-531. https://doi.org/10.2307/3207893

Butler, J. (1990). Gender trouble: Feminism and the subversion of identity. Routledge.

Caputi, J. (2016). The colour orange? Social justice issues in the first season of Orange Is the New Black. Journal of Popular Culture, 48(6), 1130-1150. https://doi.org/10.1111/jpcu.12352

Capuzza, J. (2015). What's in a name? Transgender identity, metareporting, and the misgendering of Chelsea Manning. In L. Spencer \& J. Capuzza (Eds.), Transgender communication studies: Histories, trends, and trajectories (pp. 93-11). Lexington Books.

Capuzza, J., \& Spencer, L. (2016). Regressing, progressing, or transgressing on the small screen? Transgender characters on U.S. scripted television series. Communication Quarterly, 65(2), 214-230. https://doi.org/10.1080/01463373.2016.1221438

Chaume, F. (2007). Dubbing practices in Europe: Localisation beats globalisation. Linguistica Antverpiensia, 6, 203-217. https://doi.org/10.52034/lanstts.v6i.188

Chaume, F. (2012). Audiovisual translation: Dubbing. St. Jerome.

Coupland, N. (2010). "Other" representation. In J. Jürgen, J. Östman, \& J. Verschueren (Eds.), Society and language use. Handbook of pragmatics highlights (pp. 241-260). John Benjamins. https://doi.org/10.1075/hoph.7.16cou

Di Martino, E. (2019). In support of trans linguistics as the basis for a 'sociolinguistics of variation for people and for society'. International Journal of the Sociology of Language, 256, 9-19. https://doi.org/10.1515/ijsl2018-2010

Díaz Cintas, J., \& Anderman, G. (2009). Audiovisual translation. Language transfer on screen. Palgrave Macmillan. https://doi.org/10.1057/9780230234581

Dore, M., \& Zarrelli, I. (2018). Transfeminine identity and HIV/AIDS in audiovisual translation Dallas Buyers Club and its Italian subtitled versions. In J. Williams Camus, C. Gómez Castro, A. Assis Rosa, \& C. Camus Camus (Eds.), Translation and gender: Discourse strategies to shape gender (pp. 59-78). Gender Cantabria University Press. https://doi.org/10.22429/Euc2018.080

Fejes, F., \& Petrich, K. (2009). Invisibility, homophobia and heterosexism: Lesbians, gays and the media. Critical Studies in Mass Communication, 10(4), 395-422. https://doi.org/10.1080/15295039309366878

Fois, E. (2012). Traduzione audiovisiva: Teoria e pratica dell'adattamento [Audiovisual translation: Theory and practice of adaptation]. Between, 2(4), 1-17. https://doi.org/10.13125/2039-6597/835

Gambier, Y. (2006). Multimodality and audiovisual translation. In M. Carroll, H. Gerzymisch-Arbogast, \& S. Nauert (Eds.), MuTra 2006 audiovisual translation scenarios: Conference proceedings, Eu-High-Level Scientific Conference Series. https://www.euroconferences.info/proceedings/2006_Proceedings/ 2006_proceedings.html 
Gamson, J. (2001). Talking freaks: Lesbian, gay, bisexual and transgendered families on day-time talk TV. In M. Bernstein \& R. Reimann (Eds.), Queer families, queer politics: Challenging culture and the state (pp. 68-86). Columbia University Press.

Gottlieb, H. (1992). Subtitling: A new university discipline. In C. Dollerup \& A. Loddegaard (Eds.), Teaching translation and interpreting (pp. 161-170). John Benjamins. https://doi.org/10.1075/z.56.26got

Gramling, D., \& Aniruddha, D. (2016). Introduction. Transgender Studies Quarterly, 3(3-4), 333-356. https://doi.org/10.1215/23289252-3545083

Grant, T. (2004). International directory of company histories. St. James Press.

Gupta, K. (2019). Response and responsibility: Mainstream media and Lucy Meadows in a post-Leveson context. Sexualities, 22(1-2), 31-47. https://doi.org/10.1177/1363460717740259

Heim, J. (2017). Not my queer: Queer representation in contemporary Italian serial television [PhD Dissertation, CUNY]. https://academicworks.cuny.edu/cgi/viewcontent.cgi?article=3029\&context=gc_etds

Hladky, K. N. (2013). The construction of queer and the conferring of voice: Empowering and disempowering portrayals of transgenderism in TransGeneration. In J. Campbell \& T. Carilli (Eds.), Queer media images: LGBT perspectives (pp. 101-110). Lexington Books.

Johnson, S. (2001). Who's misunderstanding whom? Sociolinguistics, public debate and the media. Journal of Sociolinguistics, 5(4), 591-610. https://doi.org/10.1111/1467-9481.00168

Johnson, S., \& Milani, T. (2010). Language ideologies and media discourse: Texts, practices, politics. Continuum.

Kerman, P. (2010). Orange Is the new black: My year in a women's prison. Abacus.

Leung, H. (2016). Always in translation. Trans cinema across languages. Transgender Studies Quarterly, 3(3-4), 433-447. https://doi.org/10.1215/23289252-3545143

Minutella, V. (2007). Translating for dubbing from English into Italian. Celid.

Monello, V. (2020). Creating "Moppa": identity construction and expressive meaning. In B. LewandoskaTomaszczyk, V. Monello, \& M. Venuti (Eds.), Language, heart, and mind. Studies at intersection of emotion and cognition (pp. 427-448). Peter Lang.

Nölke, A. (2017). Making diversity conform? An intersectional, longitudinal analysis of LGBT-specific mainstream media advertisements. Journal of Homosexuality, 65(2), 224-255. https://doi.org/10.1080/00918369.2017.1314163

Paolinelli, M., \& Di Fortunato, E. (2005). Tradurre per il doppiaggio: La trasposizione linguistica dell'audiovisivo: Teoria e pratica di un'arte imperfetta [Translating for dubbing: The linguistic transposition of audiovisual: Theory and practice of an imperfect art]. Hoepli.

Pavesi, M. (2005). La traduzione filmica: Aspetti del parlato doppiato dall'Inglese all'Italiano [Film trans/ation: Aspects of voiced speech from English to Italian]. Carocci.

Poole, R. (2017). Towards a queer futurity: New trans television. European Journal of American Studies, 12(2), 124. https://doi.org/10.4000/ejas.12093

Ranzato, I. (2015). 'God forbid, a man!': Homosexuality in a case of quality TV. Between, 5(9), 1-23.

Robinson, D. (2019). Transgender, translation, translingual address. Bloomsbury. https://doi.org/10.5040/9781501345579

Rose, E. (2020). Translating transg identity: (Re)writing undecidable texts and bodies. Routledge. https://doi.org/10.4324/9780367369972

Sandrelli, A. (2016). The dubbing of gay-themed TV series in Italy: Corpus-based evidence of manipulation and censorship. Altre Modernità, 2, 124-143. https://doi.org/10.13130/2035-7680/6852

Turkle, S. (1995). Life on the screen: Identity in the age of the Internet. Weidenfeld \& Nicholson.

Zanotti, S. (2012). Censorship or profit? The manipulation of dubbed youth films. Meta57, 2, 351-368. https://doi.org/10.7202/1013950ar

Zimman, L. (2020). Transgender language, transgender moment: Toward a trans linguistics. In R. Barrett \& K. Hall (Eds.), The Oxford handbook in language and sexuality. Oxford University Press. https://doi.org/10.1093/oxfordhb/9780190212926.013.45

Zimman, L., \& Hall, K. (2010). Language, embodiment, and the 'Third Sex'. In C. Llams \& D. Watt (Eds.), Language and identities (pp. 166-178). Edinburgh University Press.

Zottola, A. (2018). Transgender identity labels in the British press (2013-2015). A corpus-based discourse analysis. Journal of Language and Sexuality, 7(2), 237-262. https://doi.org/10.1075/jls.17017.zot 
Zottola, A. (2021). Transgender identities in the press: A corpus-based discourse analysis. Bloomsbury. https://doi.org/10.5040/9781350097575

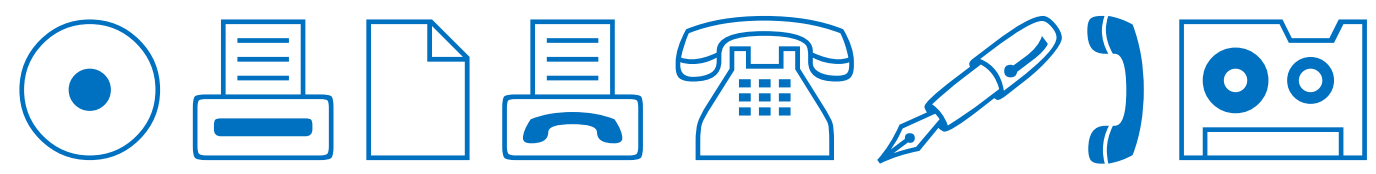

